\title{
USING THE MODIFIED STRIP YIELD MODEL FOR CRACK GROWTH UNDER VARIABLE AMPLITUDE LOADING IN AA 2124 AND AA 7475
}

\author{
UPORABA MODIFICIRANEGA SYM ZA RAST RAZPOK V \\ ZLITINAH AA 2124 IN AA 7475 PRI RAZLIČNIH POGOJIH \\ IZMENIČNIH OBREMENITEV
}

\author{
Jakub Šedek*, Roman Růžek \\ VZLÚ - Czech Aerospace Research Centre, Beranových 130, 199 05, Prague, Czech Republic \\ Prejem rokopisa - received: 2018-07-17; sprejem za objavo - accepted for publication: 2018-12-20
}

doi: $10.17222 /$ mit.2018.157

\begin{abstract}
The crack growth in metal materials under variable amplitude loading is influenced by interaction effects due to the random sorting of different load levels. The simulation of crack growth under such conditions is difficult. The Strip Yield Model (SYM) is widely used. Under certain loading sequences, the thickness effect of the specimen appears, resulting in different crack growths. The crack growth in M(T) specimens with different thicknesses made from 7475-T7351 and 2124-T851 plate materials was investigated using two flight loading sequences. During the tests, the thickness effect occurred in the case of AA 7475, but not in the case of AA 2124. The original SYM is not sensitive to specimen thickness; therefore, the modification was implemented based on the variable constraint factor $\alpha$ according to the FE analysis of the M(T) specimen. The crack-growth curves for AA 7475 determined by the modified SYM show dependency on the thickness and behave similarly to the test curves. The thinnest specimen $(2 \mathrm{~mm})$ shows a $150 \%$ longer life than the thickest one $(8 \mathrm{~mm})$. In AA 2124 , no thickness influence was observed for both the SYM prediction and the experimental results. The only exception was a slightly longer life predicted for the thinnest specimen. Using the modified SYM, the dependency on the thickness appeared similar to that obtained through experimental observations.

Keywords: crack growth, prediction, Strip Yield Model, variable amplitude loading
\end{abstract}

Na rast razpok v materialih pod spremenljivimi izmeničnimi obremenitvami vplivajo interakcijski učinki zaradi naključne razporeditve različnih nivojev obremenitev. Simulacija rasti razpoke pod takšnimi pogoji je zahtevna. SYM (angl.: Strip Yield Model) se uporablja zelo pogosto. Pod določenimi obremenitvenimi sekvencami debelina preizkušanca različno vpliva na rast razpoke. Avtorji so preučevali rast razpok v M(T) preizkušancih različnih debelin, izdelanih iz 7475-T7351 in 2124-T851 pločevin z uporabo dveh letečih obremenitvenih sekvenc. Med preizkušanjem je na rast razpoke vplivala debelina preizkušanca iz zlitine AA 7574, v primeru zlitine AA 2124 pa vpliva debeline niso zaznali. Originalni SYM ni občutljiv na debelino preizkušanca, zato so avtorji uvedli modifikacijo, temelječo na konstantnem faktorju $\alpha \mathrm{v}$ skladu $\mathrm{z}$ analizo na osnovi metode končnih elementov $\mathrm{M}(\mathrm{T})$ preizkušanca. Krivulja rasti razpoke za zlitino AA 7475, določena s pomočjo SYM, kaže na odvisnost od debeline in se obnaša podobno kot testne krivulje. Najtanjši vzorec (debeline $2 \mathrm{~mm}$ ) je imel $150 \%$ daljšo življenjsko dobo kot najdebelejši (debeline $8 \mathrm{~mm}$ ). V zlitini AA 2124 vpliva debeline preizkušancev avtorji niso zaznali niti pri SYM napovedi niti pri eksperimentalnem rezultatu (preizkusu). Edina izjema je bila malenkostno daljša življenjska doba pri najtanjšem preizkušancu. Uporaba modificiranega SYM je pokazala podoben vpliv, kot so ga avtorji dobili z eksperimentalnim opazovanjem.

Ključne besede: rast razpok, napoved, SYM (Strip Yield Model), spremenljive izmenične obremenitve

\section{INTRODUCTION}

The crack growth under variable amplitude loading is a complicated phenomenon that is still not fully understood. The interaction effects of overloading and underloading cycles occur and have significant influence on the crack growth rate, especially in metallic materials. To predict the crack growth, several models were introduced in the past, primarily using the deterministic approach. ${ }^{1-5}$ Among these models, the Strip Yield Model (SYM) is widely used currently because other models require specific routines for a determination of the material characteristics and model coefficients. Several models also

*Corresponding author e-mail: sedek@vzlu.cz need adaptation to specific loading sequences; therefore, the versatility is not guaranteed.

The experimental observations of crack growth under variable amplitude loading show the dependency of specimen lives on the thickness under certain cycle sequences. ${ }^{6-8}$ The simulation of crack growth is therefore more complicated. The original SYM does not cover the thickness effect, but several attempts to modify the SYM have been implemented. ${ }^{9-11}$ The modifications include incorporating the thickness dependency through the variable constraint factor $\alpha$, which is correlated to the stress state at the crack tip. The plane stress, the plane strain or the transitional state is evaluated based on the size and the thickness of the plastic zone.

In this work, the modification of SYM similar to Guo $^{11}$ but with an enhanced variable constraint factor $\alpha$ in terms of dependence on the overload is used. 


\section{EXPERIMENTAL PART}

The crack growth in middle cracked tension specimens $\mathrm{M}(\mathrm{T})$ made from aluminium alloys 7475-T7351 and 2124-T851 was investigated. The ultimate strength of both alloys is similar, and the yield stress differs by $7 \%$, but the elongation is almost twice as great for AA 7475 as for AA 2124 (see Table 1).

Table 1: Material characteristics of AA 2124 and AA 7475

\begin{tabular}{|c|c|c|c|c|c|}
\hline & $\begin{array}{c}\text { Yield } \\
\text { stress } \\
(\mathrm{MPa})\end{array}$ & $\begin{array}{c}\text { Ultimate } \\
\text { strength } \\
(\mathrm{MPa})\end{array}$ & $\begin{array}{c}\text { Elon- } \\
\text { gation } \\
(\%)\end{array}$ & $\begin{array}{c}C- \\
\text { coeffi- } \\
\text { cient of } \\
\text { Paris } \\
\text { law }\end{array}$ & $\begin{array}{c}m- \\
\text { coeffi- } \\
\text { cient of } \\
\text { Paris } \\
\text { law }\end{array}$ \\
\hline AA 2124-T851 & 447 & 488 & 8.3 & $1.20 \mathrm{e}-10$ & 3.3 \\
\hline AA 7475-T7351 & 419 & 486 & 15 & $1.50 \mathrm{e}-10$ & 3.3 \\
\hline
\end{tabular}

The experimental evaluation of crack growth was carried out on specimens with different thicknesses of $(2$, 4 and 8) $\mathrm{mm}$ made from plates with thicknesses of 50 $\mathrm{mm}$ (AA 2124) and $76 \mathrm{~mm}$ (AA 7475). The specimen length of $250 \mathrm{~mm}$ and width of $100 \mathrm{~mm}$ were used. Fatigue crack growth tests were carried out using a hydraulic SCHENCK load frame with a capacity of $250 \mathrm{kN}$. The load frame was controlled by an INSTRON FastTrack 8800 test control system. This approach provides real-time closed-loop control, including transducer conditioning and function generation. Specimens were clamped into the test frame using mechanical grips. The
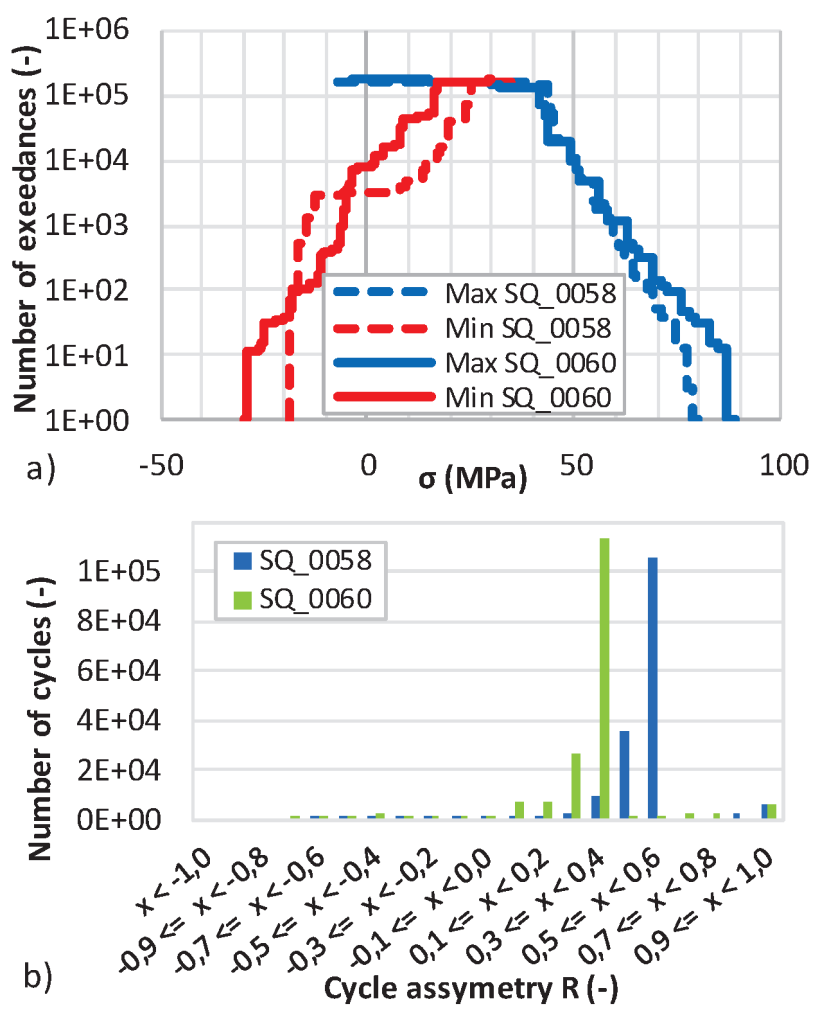

Figure 1: Loading sequences SQ 0058 and SQ 0060: a) Exceedance plot of load levels, b) distribution of the ratio $R$ of cycle asymmetry test procedure was conducted in agreement with the requirements of the ASTM E-647 standard. ${ }^{12}$ Fatigue crack initiation and propagation were monitored via a visual method using an Olympus SZ40 light stereo microscope with a maximum magnification of $40 \times$. Cracklength measurements were performed on both surfaces and sides relative to the longitudinal axes of the specimens.

The tests with constant amplitude loading at different load ratios $R$ were primarily conducted on the specimens with the above-defined thickness range in order to determine the material data of the crack growth, which for both alloys are very similar (see Table 1). The crack growth rate data were represented by the Paris law in the form

$$
\frac{\Delta a}{\Delta N}=C \Delta K_{\mathrm{eff}}^{m}
$$

where $\Delta a / \Delta N$ denotes the crack growth rate and $\Delta K_{\text {eff }}$ is the amplitude of the effective stress intensity factor. Coefficients $C$ and $m$ are the characteristics of the crack growth rate curve. The dependency $\Delta a / \Delta N=f\left(\Delta K_{\mathrm{eff}}\right)$ was determined by processing the crack growth data for different $R$ in the form $\Delta a / \Delta N=f(\Delta K(R))$. In this procedure, the Newman's Crack Opening Stress Equation was employed. ${ }^{13}$

The variable amplitude loading was realized by sequences of cycles representative for a lower wing panel of a commuter airplane. Sequences with internal labelling of SQ_0058 and SQ_0060 were applied. The exceedance plots of both sequences are shown in Figure 1a. The cycles with load ratio $R$ in the ranges of $0.5-0.6$ and $0.3-0.4$ are the most numerous for the sequences SQ_0058 and SQ_0060, respectively. The shift in the ratio of 0.2 can be seen in Figure $\mathbf{1 b}$.

During tests under variable amplitude loading, the different lives for 2-, 4- and 8-mm-thick specimens were determined for the sequence SQ_0060 applied on AA 7475. Generally, the thinner the specimen, the longer the life obtained. In contrast, for the sequence SQ_0058 applied on AA 2124, no difference was observed.

\section{SIMULATION USING STRIP YIELD MODEL}

The Strip Yield Model used for simulation of crack growth is based on Newman's model, ${ }^{5}$ but it is modified by the variable constraint factor $\alpha \cdot{ }^{14,15}$ The model consists of a fictitious crack in the elastic body loaded not only by remote stress and yield strips mainly in the region of the plastic zone but also in the wake of the crack when unloaded. The model determines the opening stress based on the history of applied cycles. The modification is implemented in two ways:

The idea of thickness dependency according to Guo ${ }^{11}$ is implemented based on the numerical analysis of the constraint factor $\alpha .{ }^{14}$ Between the plane stress and plane strain, the value of $\alpha$ is described by a sigmoidal curve 
(in semi-log plot) based on the ratio of the thickness $B$ and the plastic zone size $r_{\mathrm{p}}$. In this work, the variable $\alpha$ is expressed in the form:

$$
\alpha=1.11+\frac{\frac{1}{1-2 v}-C_{\alpha}}{1+50\left(\frac{r_{\mathrm{p}}}{B}\right)^{2}}
$$

where $C_{\alpha}$ is the coefficient according to the specimen type and $v$ denotes Poisson's ratio.

The dependence of the variable constraint factor $\alpha$ on the load level after overload is implemented according to the numerical analysis of the factor development during cyclic loading. ${ }^{15}$ If the plastic zone from the actual cycle is smaller than the rest of the plastic zone from the overload, the factor $\alpha$ is computed as:

$$
\alpha=a_{\mathrm{p}}-\left(a_{\mathrm{p}}-\left(a_{\mathrm{LC}}+\left(a_{\mathrm{UC}}-a_{\mathrm{LC}}\right) k_{1}\right)\right)\left(1-\alpha_{\mathrm{p}_{2}}^{\gamma_{\mathrm{SYM}}}\right)
$$

where $\alpha_{\mathrm{p}}$ denotes the value of $\alpha$ when the primary plastic zone in the virgin material is created and $\alpha_{\mathrm{LC}}$ and $\alpha_{\mathrm{UC}}$ are the values at the borders of possible values of $\alpha$ after overload $\left(\alpha_{\mathrm{LC}}=\right.$ minimum and $\alpha_{\mathrm{UC}}=$ maximum $)$. The coefficient $\kappa_{1}$ evaluates the load level after overload and $\kappa_{2}$ evaluates the position of the crack tip in the plastic zone from overload. These coefficients are driven internally by the model based on the opening stress and the position of the crack tip.

The cycles in a sequence pass the model in chronological order cycle-by-cycle; therefore, no counting method is applied. The simulation of crack growth was performed for constant amplitude loading and for variable amplitude loading for several specimen thicknesses, as well.

\section{RESULTS}

The results of the analysis are the simulated crackgrowth curves determined by the SYM. Simulations by the modified SYM under constant amplitude loading matched well with the experimental lives of the tested specimens. The difference was $\pm 20 \%$ for both alloys. The load level and the cycle asymmetry were the main parameters; no thickness dependency appeared.

The modified SYM showed the sensitivity to the specimen thickness during variable amplitude loading by sequence SQ_0060 applied on AA 7475, as observed in the experimental test (see Figure 2a). The thinnest specimen $(2 \mathrm{~mm})$ yielded the longest life. In the crack growth curve, there is a section of constant rate. The modified SYM behaves similarly and shows a comparable curve. In the case of the thickest specimen $(8 \mathrm{~mm})$, the match of the crack growth curves was also good; only the 4-mm-thick specimen showed a slightly large difference of $16 \%$ between the simulation and the test lives, but the curve also lay between the thickest and the thinnest specimen.
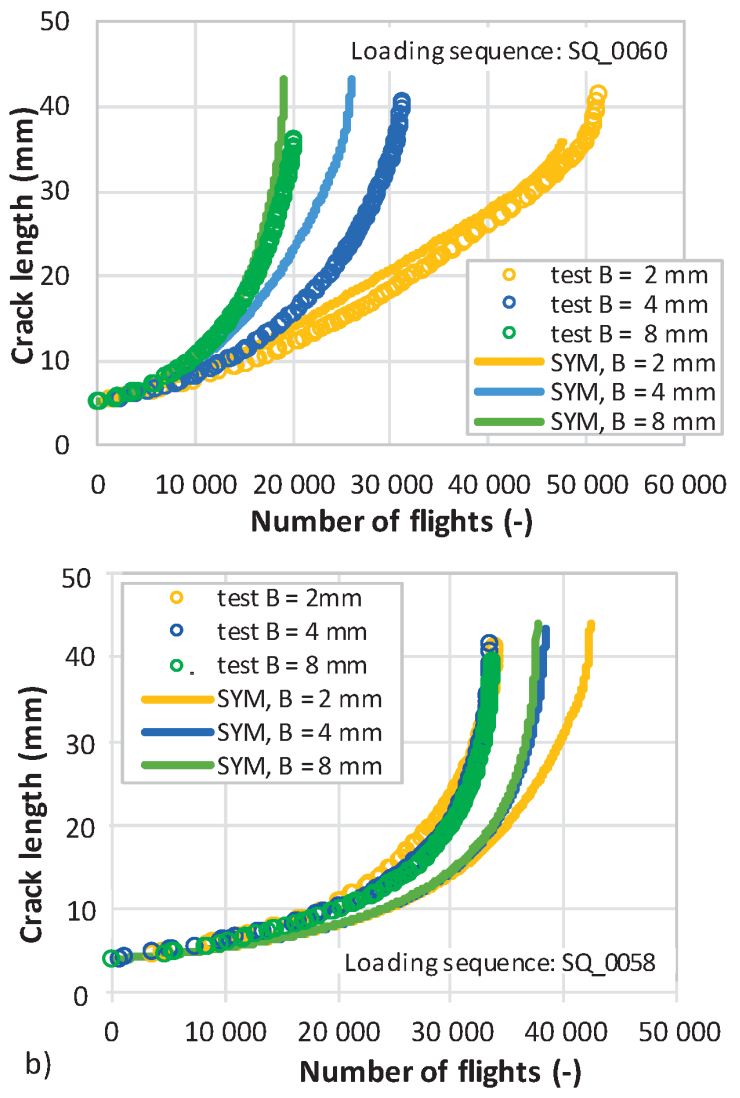

Figure 2: Crack-growth curves for the test and simulation using modified SYM: a) AA 7475-T7351 and loading sequence SQ_0060, b) AA 2124-T851 and loading sequence SQ_0058

The sequence SQ_0058 applied on AA 2124 revealed no dependency on the specimen thickness during tests. The same behaviour was obtained by the modified SYM; only the thinnest specimen showed a little retardation at the longer crack length in the simulation (see Figure 2b). The simulated lives for specimens with thicknesses of (4 and 8) $\mathrm{mm}$ were $12 \%$ longer than in the tests. The 2-mm-thick specimen deviated from the length of $15 \mathrm{~mm}$ and as a result, the life was $26 \%$ longer.

\section{DISCUSSION}

The thickness effect under variable amplitude loading was experimentally observed in AA 7475 under the sequence of cycles SQ_0060. The second sequence applied on AA 2124 does not show the thickness effect. The simulation using SYM gives very similar results compared with the experimental data. The thickness effect under variable amplitude loading seems to be attributed to the loading sequence of the applied cycles. The difference between both alloys in terms of basic material characteristics is not significant. Only one of the basic material properties differs, i.e., elongation; AA 7475 is more ductile. If the ductility influences the plastic zone at the crack tip such that the stress and strain fields are different, the crack-growth behaviour at high 
load ratios can differ, as well. The SYM does not take into account the ductility and therefore no severe difference in the predicted crack growth curves can be expected when comparing both alloys under the same loading sequence. However, it can be stated that no other prediction model takes into account the influence of elongation.

The SYM results are in sufficient conformity with the experimental data. A maximum of $26 \%$ difference between the predicted and experimental data was achieved for all the investigated thicknesses and sequences. The match in crack growth of the 2-mm-thick specimen in AA 2124 in comparison with 4-mm- and 8-mm-thick specimens could be attributed partly to the scatter in the material data. During the experimental crack growth in AA 2124 the thinnest specimen was a little faster in small crack lengths and slower at higher crack lengths than the other specimens, and finally, the resulting life was almost the same. The prediction does not take into account the scatter of the material characteristics and the sensitivity analysis should be performed to prove the variability of the results in dependence of the inputs. Also, more precise adjustment of the SYM could be suitable because the difference in crack growth is present at higher crack length, where the stress-intensity factor is higher and the retardation effect is more severe.

\section{CONCLUSIONS}

The influence of specimen thickness and different $\alpha$ values after overload were used in the modification of the Strip Yield Model (SYM). Simulations considering the thickness of the specimen under variable amplitude loading were performed for two materials and sequences. Both sequences showed similar simulated crack growth behaviour to the experimental data. The obvious plateau in the crack growth rate was captured well for the thinnest specimen from AA 7475. In this case, the thinner specimen yielded a longer crack growth life compared to the thicker one. Nevertheless, the second sequence applied on AA 2124 did not show this behaviour and no difference in the crack-growth curves was observed. Generally, the simulated crack-growth curves obtained by modified SYM were similar to those experimentally determined in the range up to $26 \%$. Regardless of whether the thickness effect appeared, the modified SYM described the crack growth sufficiently well.

\section{Acknowledgement}

This work was funded by the Ministry of Industry and Trade of the Czech Republic in the framework of the Institutional Support of Research Organizations.

\section{REFERENCES}

${ }^{1}$ J. Willenborg, A crack growth retardation model using an effective stress concept, Technical memorandum 71-1-FBR (AFFDL-TM71-1-FBR), 1971

${ }^{2}$ O. E. Wheeler, Spectrum loading and crack growth, J. of Basic Engineering, Trans. ASME, 94 (1972) 1, Series D, 181

${ }^{3}$ G. Baudin, M. Robert, Crack growth model for flight type loading, Proc. of the $11^{\text {th }}$ ICAF Symp., Noordwijkerhout, 1981

${ }^{4}$ A. U. de Koning, H. H. van der Linden, Prediction of fatigue crack growth rates under variable amplitude loading, Report NLR MP 81023U, National Aerospace Laboratory, Amsterdam 1981

${ }^{5}$ J. C. Newman Jr., A crack closure model for predicting fatigue-crack growth under aircraft spectrum loading, NTM (Nasa Technical memorandum) 81941, NASA LRC 1981

${ }^{6}$ H. R. Shercliff, N. A. Flec, Effect of specimen geometry on fatigue crack growth in plane strain - II overload response, Fatigue \& Fracture of Engineering Materials \& Structures, 13 (1990) 3, 287-296

${ }^{7}$ C. C. Turner, C. D. Craman, B. M. Hillberry, Fatigue crack closure behaviour at high stress ratios, Mechanics of fatigue crack closure, ASTM, STP (Selected technical papers) 982, Philadelphia 1988, 528-535

${ }^{8}$ R. Růžek, P. Homola, M. Kakos, Experimental verification of thickness effects on fatigue crack growth in an AA 7475 plate, Proc. of the EAN - 55th Conf. on Experimental Stress Analysis, Nový Smokovec, 2017, 513-518

${ }^{9}$ G. S. Wang, A. F. Blom, A strip model for fatigue crack growth predictions under general load conditions, Engng. Fracture Mech., 40 (1991) 3, 507-533

${ }^{10}$ T. Machniewicz, Yield stress modification in the strip yield model, Mechanics and Control, 31 (2012) 4, 150-157

${ }^{11}$ W. Guo, C. H. Wang, L. R. F. Rose, The influence of cross-sectional thickness on fatigue crack growth, Fatigue Fract. Eng. Mater. Struct., 22 (1999) 5, 437-444

${ }^{12}$ ASTM E 647-15e1:2015 Standard test method for measurement of fatigue crack growth rates, ASTM International, West Conshohocken, USA

${ }^{13}$ J. C. Newman Jr., A crack opening stress equation for fatigue crack growth, International Journal of Fracture, 24 (1984) 3, R131-R135

${ }^{14} \mathrm{~J}$. Šedek, Numerical investigation of 3-D strain constraint in lab test specimens, Proc. of the $55^{\text {th }}$ Conf. on Experimental Stress Analysis, Nový Smokovec, 2017, 174-177

${ }^{15}$ J. Šedek, R. Růžek, Thickness effect analysis on fatigue crack propagation of 7475 plate material under variable amplitude loading, MATEC Web of Conferences, 188 (2018) 02015, doi:10.1051/ matecconf/201818802015 